\title{
YIELD OF TOCOSH FLOUR IN TWO POTATO VARIETIES (SOLANUM TUBEROSUM) AND THEIR CHARACTERISTICS
}

Jorge Jave Nakayo

Universidad Nacional Mayor de San Marcos - UNMSM, Lima, (Perú). E-mail: jorge.jave@unmsm.edu.pe ORCID: https://orcid.org/0000-0003-3536-881X

Verónica Espinel Pino

Universidad Técnica de Manabi, Manabi, (Ecuador)

E-mail: vespinel@utm.edu.ec ORCID: https://orcid.org/0000-0002-7604-7599

Jorge Luis López Bulnes

Universidad Nacional Mayor de San Marcos - UNMSM, Lima, (Perú). E-mail: jlopezb@unmsm.edu.pe ORCID: https://orcid.org/0000-0002-9583-1143

Violeta Vega Ventosilla

Universidad Nacional Federico Villarreal - UNFV, Lima, (Perú). E-mail: vvega@unfv.edu.pe ORCID: https://orcid.org/0000-0002-7763-6993

\section{Gitación sugerida Suggested citation}

Jave,J., Espinel, V., López, J. L., y Vega, V. (2020). Yield of tocosh flour in two potato varieties (solanum tuberosum) and their characteristics. 3C Tecnología. Glosas de innovación aplicadas a la pyme. Edición Especial, Noviembre 2020, 149-159. https://doi.org/10.17993/3ctecno.2020.specialissue6.149-159 


\section{ABSTRACT}

In the present investigation it allows to demonstrate the yield of the flour of tocosh of two varieties of potato (solanum tuberosum) canchán and native variety of "calamarca The raw material was acquired in the district of Paucartambo province of Pasco department of Pasco, to $2880 \mathrm{msnm}$. For the experimental study the two varieties of potatoes were placed using as technique a pool with a water current with varied times, where the microorganisms act and increase their activity related to the acidity. The evaluation was made using the tukey trial to compare the two varieties, obtaining results for the native variety "calamarca" which had a fermentation time of 45 days to have all the conditions to be tocosh with a flour yield of $59.6 \%$ compared to the variety of canchán whose fermentation time was 31 days with a yield of $45 \%$.

\section{KEYWORDS}

Tocosh, Yield, Solanum tuberosum, Potato, Calamarca, Flour. 


\section{INTRODUCTION}

Potato is undoubtedly one of the most important crops in the country Peru has more than 5,000 potato varieties in terms of area planted (260,000 ha/year), number of producers who depend on it $(600,000)$, contribution to the national economy $(11.3 \%$ of agricultural GDP) and to the human diet (average consumption of $68.4 \mathrm{~kg} /$ inhabitant/year). Potato tocosh is a naturally processed potato for nutritional and healing purposes of traditional Peruvian medicine (Velasco-Chong, et al., 2020). The potato is produced in 19 of Peru's 24 departments, which demonstrates its plasticity in terms of adaptation. As the centre of origin of the potato, Peru maintains a culture of diversity; for this reason, in the mountains, it is common today to find mixed agriculture with native and improved varieties (VelascoChong, et al., 2020).

Straw or "ichu" and pressed mechanically with stones under a stream of water from a spring. This treatment gives products nutritional and therapeutic properties used only by those who know and consume them and which could be a natural alternative to alleviate, prevent or cure some diseases (Sandoval et al., 2015), a product obtained thanks to butyric fermentation, while this product has an unpleasant smell, which is a limitation for its consumption in most of the population, this product offers a diversity of health benefits, which is why it is reason to study to find the solution for which this limitation should be a problem in consumer acceptance (Quispe et al., 2020).

We will use two varieties, which will be placed, in a well with a stream of water in a varied time, in which microorganisms act that in turn will increase the activity related to acidity. It seeks to extend the life of a product, transforming it into another as is tocosh flour; evaluate the sensory and physicochemical properties. To make the comparison between two varieties that will produce results that can show us which of them has better properties; better yield and that ferments in less time (Carranza et al., 2020).

We will determine the results based on tocosh in the varieties of potatoes Yungay and Conchán that come from the district of Paucartambo (Agricultural and Hydroelectric Valley) with an altitude of 2880 meters above sea level, province of Pasco in the department of Pasco. 


\section{METHODOLOGY}

The raw material for this study was acquired from the district of Paucartambo province of Pasco department of Pasco, at 2880 meters above sea level the varieties of potato solanum tuberosum used are Canchan and native Calamarca.

For the experimental study were placed the two varieties of potatoes in a pool with a water current with varied times in order that the microorganisms act and increase their activity related to the acidity.

The parameters considered for the elaboration of the tocosh were: ambient temperature between $\mathrm{d} 10$ and $18{ }^{\circ} \mathrm{C}$ Water temperature between 5 and $15{ }^{\circ} \mathrm{C}$ average storage time 30 days H $6.0 \pm 2.0$ (Alvarado et al., 2020).

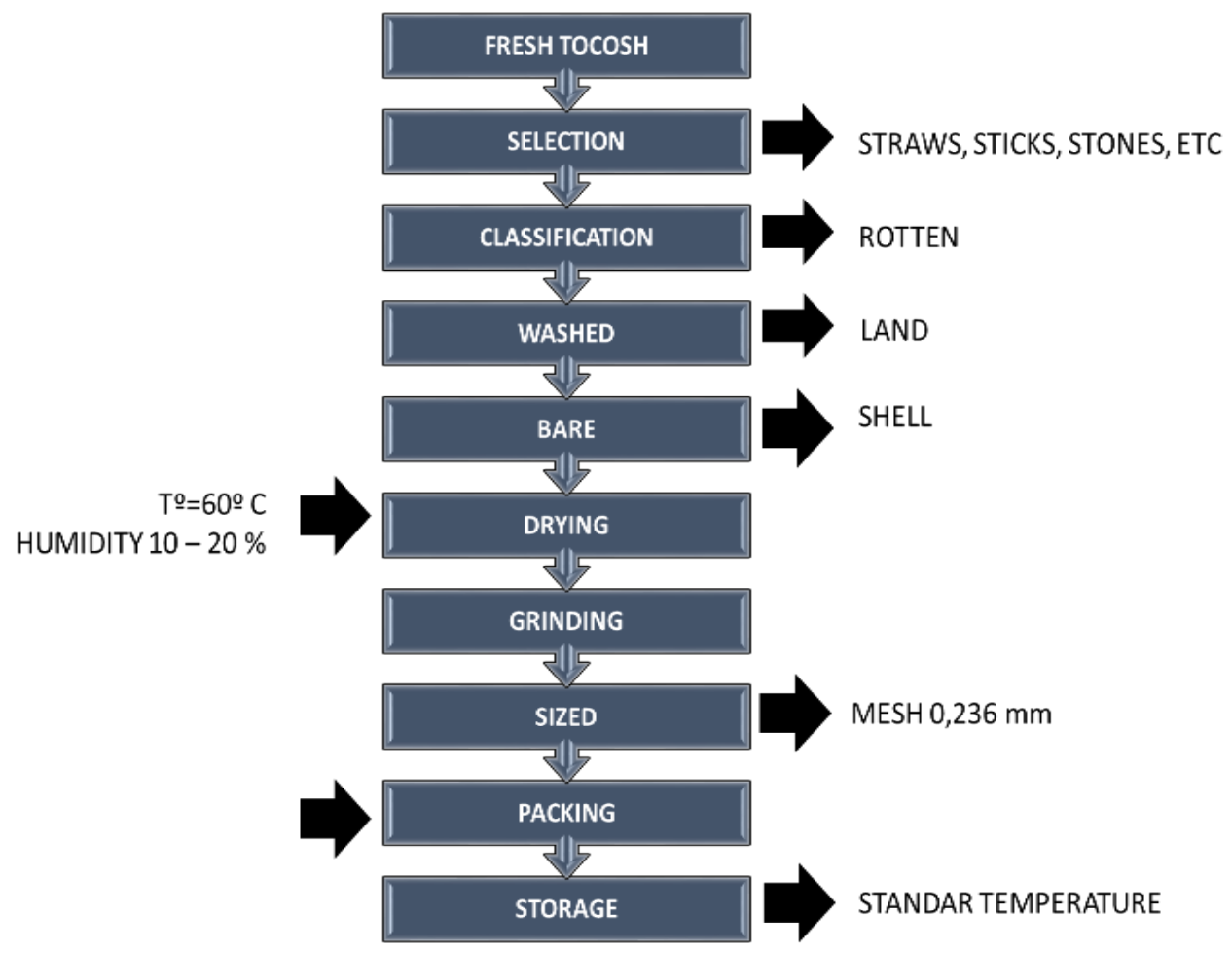

Figure 1. Flowchart of tocosh flour processing (self-made source).

Figure 1 shows the unit operations for the processing of tocosh of the two varieties under study by which the results for the present study will be obtained. 


\section{RESULTS}

The yield in the production of tocosh flour obtained with the flow of tocosh flour processing figure 1 for each variety of potato in the study was: $59.60 \%$, for the native variety $45 \%$, variety of canchan.

The fermentation time for the native variety was 45 days and for the canchan variety was 45 days.

Table 1. Evaluation of physicochemical characteristics during fermentation (Canchan variety).

\begin{tabular}{|c|c|c|c|c|c|}
\hline Control & & General appearance & Smell & $\mathbf{P h}$ & $\mathbf{T}$ \\
\hline 1 & $14 / 04 / 2019$ & $\begin{array}{l}\text { Smooth shell with } \\
\text { hard consistency, } \\
\text { characteristic of the } \\
\text { potato. }\end{array}$ & $\begin{array}{l}\text { Characteristic of } \\
\text { the potato }\end{array}$ & 6.56 & $9^{\circ} \mathrm{C}$ \\
\hline 2 & $21 / 04 / 2019$ & $\begin{array}{l}\text { Soft shell of soft } \\
\text { consistency }\end{array}$ & $\begin{array}{l}\text { Strong fermentation } \\
\text { odor }\end{array}$ & 6.40 & $9^{\circ} \mathrm{C}$ \\
\hline 3 & $28 / 04 / 2019$ & $\begin{array}{l}\text { Soft shell with soft } \\
\text { consistency }\end{array}$ & $\begin{array}{l}\text { Strong fermentation } \\
\text { odor }\end{array}$ & 80 & $9^{\circ} \mathrm{C}$ \\
\hline 4 & 05/05/2019 & $\begin{array}{l}\text { Soft shell with soft } \\
\text { consistency }\end{array}$ & $\begin{array}{c}\text { Strong fermentation } \\
\text { odor }\end{array}$ & 5.20 & $9^{\circ} \mathrm{C}$ \\
\hline 5 & $12 / 05 / 2019$ & $\begin{array}{l}\text { Robust housing with } \\
\text { soft consistency, tocosh } \\
\text { feature }\end{array}$ & Tocosh feature & 4.70 & $9^{\circ} \mathrm{C}$ \\
\hline
\end{tabular}

Table 1 shows the evaluation of the physicochemical characteristics during fermentation (Canchan variety), the dates of the controls of its structural changes and its odours, the $\mathrm{pH}$ and the temperatures of each sample.

The fermentation of the Canchan potato variety in the production of tocosh flour begins at a $\mathrm{pH}$ of 6.56 and ends at a $\mathrm{pH}$ of 4.70 .

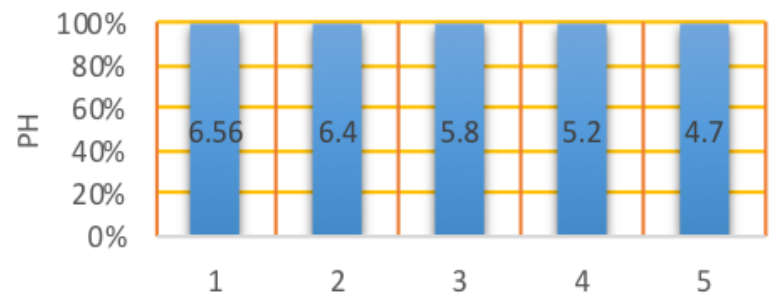

Figure 2. $\mathrm{PH}$ variation at $9^{\circ} \mathrm{C}-\mathrm{PAPA} \mathrm{CANCHAN}$. 
In Figure 2, the general appearance and smell of the potato changes during the fermentation process; starting the fermentation of the potato in study with smooth skin, hard consistency and characteristic smell of fresh and finished potato.

Table 2. Evaluation of physicochemical characteristics during fermentation (native variety).

\begin{tabular}{|c|c|c|c|c|c|}
\hline Control & & General appearance & Smell & $\mathbf{P h}$ & $\mathbf{T}$ \\
\hline 1 & $14 / 04 / 2019$ & $\begin{array}{l}\text { Smooth shell with hard consistency, } \\
\text { characteristic of the potato }\end{array}$ & $\begin{array}{l}\text { Characteristic of } \\
\text { the potato }\end{array}$ & 6.88 & $9 \circ \mathrm{C}$ \\
\hline 2 & $21 / 04 / 2019$ & $\begin{array}{l}\text { Characteristic of the smooth potato } \\
\text { peel of soft consistency }\end{array}$ & $\begin{array}{l}\text { Strong fermentation } \\
\text { odor }\end{array}$ & 6.30 & $9 \circ \mathrm{C}$ \\
\hline 3 & 28/04/2019 & Smooth, hard consistency shell & $\begin{array}{l}\text { Strong fermentation } \\
\text { odor }\end{array}$ & 6.15 & $9 \circ \mathrm{C}$ \\
\hline 4 & 05/05/2019 & Smooth, hard consistency shell & $\begin{array}{l}\text { Strong fermentation } \\
\text { odor }\end{array}$ & 5.90 & $9 \circ C$ \\
\hline 5 & $12 / 05 / 2019$ & Soft rough skin. & $\begin{array}{l}\text { Strong fermentation } \\
\text { odor }\end{array}$ & 5.60 & $9 \circ \mathrm{C}$ \\
\hline 6 & 19/05/2019 & Rough shell with a soft consistency. & $\begin{array}{l}\text { Strong fermentation } \\
\text { odor }\end{array}$ & 5.00 & $9 \circ \mathrm{C}$ \\
\hline 7 & $25 / 05 / 2019$ & Rough shell of soft consistency. & $\begin{array}{l}\text { Strong fermentation } \\
\text { odor }\end{array}$ & 4.50 & $90 \mathrm{C}$ \\
\hline 8 & 01/06/2019 & Roughened shell of soft consistency. & Tocosh feature & 4.15 & $90 \mathrm{C}$ \\
\hline
\end{tabular}

Table 2 shows the evaluation of the physicochemical characteristics during fermentation (Nativa variety), the dates of controls of its structural changes and odours, the $\mathrm{pH}$ and temperatures of each sample.

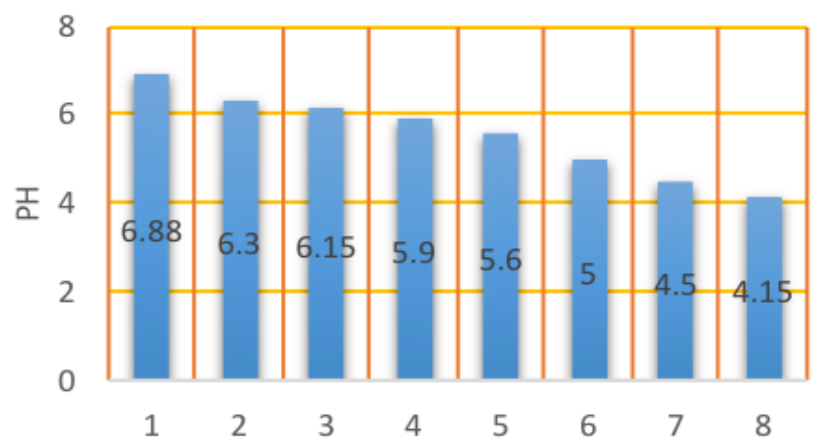

Figure 3. $\mathrm{PH}$ variation at $9^{\circ} \mathrm{C}$ - NATIVE POTATO.

Figure 3 shows that the general appearance and odour of the potato changes during the fermentation process; the two varieties of potatoes under study with smooth skin, hard consistency and odour characteristic of fresh and finished potatoes start to ferment. 


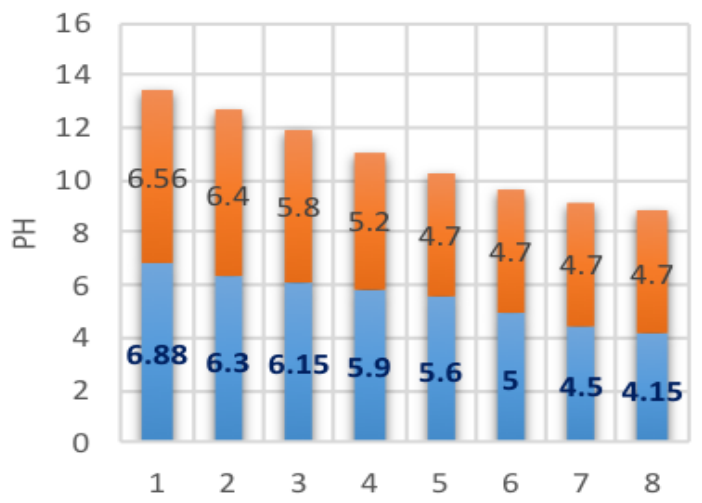

Figure 4. PH comparison PAPA NATIVA vs. CANCHAN.

In Figure 4 we can see the comparison of the two varieties of parasites used in the experiment, also seeing the values between the two varieties there is a significant difference.

Table 3. Analysis of variance, Tukey "flavour attribute".

\begin{tabular}{|c|c|c|c|c|c|c|}
\hline SOURCE & GI & $\begin{array}{c}\text { SC } \\
\text { AJUST. }\end{array}$ & $\begin{array}{c}\text { MC } \\
\text { AJUST. }\end{array}$ & VALUE F & $\begin{array}{c}\text { PROBABILITY } \\
\text { VALUE }\end{array}$ & VALUE P \\
\hline Factor & 1 & 3.125 & 3.1250 & 4.52 & $7,1043 E-19$ & 0.042 \\
\hline Error & 30 & 20.750 & 0.6917 & & & \\
\hline Total & 31 & 23.875 & & & \\
\hline
\end{tabular}

In Table 3, the comparison of the treatments of the two potato varieties by Tukey's taste attribute test, it is observed that the $\mathrm{T} 2$ treatment (tocosh - made from the native potato) statistically has a difference with the $\mathrm{T} 1$ treatment (tocosh made from the canchan potato), which means that the $\mathrm{T} 2$ treatment has better organoleptic attributes on average than the T1 treatment.

Table 4. Analysis of Variance, Tukey "consistency attribute.

\begin{tabular}{|c|c|c|c|c|c|c|}
\hline SOURCE & GI & $\begin{array}{c}\text { SC } \\
\text { AJUST. }\end{array}$ & $\begin{array}{c}\text { MC } \\
\text { AJUST. }\end{array}$ & $\begin{array}{c}\text { VALUE } \\
\text { F }\end{array}$ & $\begin{array}{c}\text { PROBABILITY } \\
\text { VALUE }\end{array}$ & $\begin{array}{c}\text { VALUE } \\
\text { P }\end{array}$ \\
\hline Factor & 1 & 6.125 & 6.1250 & 7.86 & $7,1043 E-19$ & 0.009 \\
\hline Error & 30 & 23.375 & 0.7792 & & & \\
\hline Total & 31 & 29.500 & & & \\
\hline
\end{tabular}

Table 4 shows the comparison of the treatments of the two potato varieties by Tukey's consistency attribute test. It is observed that the T2 treatment (tocosh made from native 
potato) has a statistical difference with the $\mathrm{T} 1$ treatment (tocosh made from canchan potato). This means that the $\mathrm{T} 2$ treatment has better organoleptic attributes on average than the T1 treatment.

Table 5. Analysis of Variance, Tukey "appearance attribute.

\begin{tabular}{|c|c|c|c|c|c|c|}
\hline SOURCE & GI & $\begin{array}{c}\text { SC } \\
\text { AJUST. }\end{array}$ & $\begin{array}{c}\text { MC } \\
\text { AJUST. }\end{array}$ & $\begin{array}{c}\text { VALUE } \\
\text { F }\end{array}$ & $\begin{array}{c}\text { PROBABILITY } \\
\text { VALUE }\end{array}$ & VALUE P \\
\hline Factor & 1 & 2.531 & 2.5312 & 4.48 & $7,1043 E-19$ & 0.043 \\
\hline Error & 30 & 16.938 & 0.5646 & & & \\
\hline Total & 31 & 19.469 & & & \\
\hline
\end{tabular}

In Table 5 the comparison of the treatments of the two varieties of potatoes by Tukey's test of the general appearance attribute, it can be seen that the $\mathrm{T} 2$ treatment (tocosh made from native potato) has a statistical difference with the $\mathrm{T} 1$ treatment (tocosh made from canchan potato), which means that the $\mathrm{T} 2$ treatment has better organoleptic attributes on average than the $\mathrm{T} 1$ treatment.

The result obtained from the organoleptic attributes of the two potato varieties applying the tukey test statistic found that the $\mathrm{T} 2$ treatment corresponding to the native potato variety presents on average better organoleptic attributes than the $\mathrm{T} 1$ treatment (tocosh made from canchan potato).

\section{DISCUSSION}

\subsection{FROM THE STUDY OF THE FERMENTATION OF EACH POTATO}

Variety of physicochemical characteristics. In this sense, the potato experiences a decrease in $\mathrm{pH}$ until it obtains the tocosh and therefore an increase in acidity (Machaca \& Mamani, 2020). Tocosh comes from a fermentation process (Andean technique), which is suitable for distribution and consumption in the different markets of Peru as flour or in its raw form. On the other hand, the amount of glycoalkaloids are related to the cultivation method, storage and temperature, depending overall on the Andean techniques destined for its production and can be distributed in different rates in Solanum tuberosum tubers, they have been found in the tuber (smaller quantity), leaves and peel (greater quantity), and some 
analysis showed quantities such as 300-600 mg/kg in peel, 2000-4000 mg/kg in buds, and 3000-5000 $\mathrm{mg} / \mathrm{kg}$ in flowers.

As for changes during the fermentation process of the general appearance and smell of the potato. The phenomenon of transformation of the potato Tocosh loses water and its volume is reduced by about half with the exception of the skin, therefore the Tocosh skin is rough "wrinkled" and the consistency soft; on the other hand, after the fermentation process, it achieves a very peculiar smell that is unpleasant, being less pronounced at the end of fermentation (Velasco-Chong, et al., 2020).

\subsection{FERMENTATION TIME FOR EACH POTATO VARIETY}

The fermentation of the potato in the production of tocosh should last from 30 to 90 days depending on the variety, size of the potato and the temperature of the water (Bustos, 2018).

Considering that the potatoes of each variety studied had uniform sizes and fermented in continuous pools with the same conditions in terms of water temperature. You could "make sure that the difference in fermentation time is due to the particular characteristics of each potato variety used in the study (Barrera et al., 2018).

\subsection{YIELD OF FRESH TOCOSH AND TOCOSH FLOUR BY POTATO VARIETIES UNDER STUDY}

Machaca and Mamani (2020) mentions that the yield in tocosh production is 30 to $45 \%$, depending on these values of the potato variety used. The variety with the highest solids, including the highest amount of starch, will have a higher yield in obtaining tocosh.

On the other hand, indicates that the yield per process in obtaining tocosh flour is 35 to $60 \%$ depending on the humidity of the flour desired. Tocosh flour, like other flours, must contain a maximum of $12 \%$ humidity to guarantee its conservation.

According to the above, we can say that the yield of the process in the production of tocosh for each variety of potato in study is 33.80 to $53.00 \%$. While the yield per process in the 
production of tocosh flour is 42.80 to $60.00 \%$; which are within the range established by the mentioned authors (Sandoval et al., 2015).

The tocosh flour did not present toxicity at the repeated dose for 28 days in the highest dose corresponding to $1000 \mathrm{mg} / \mathrm{kg}$ BW. There were no deaths at up to $5000 \mathrm{mg} / \mathrm{kg} \mathrm{BW}$, therefore, the oral LD50 was greater than $5000 \mathrm{mg} / \mathrm{kg}$ (Velasco-Chong, et al., 2020).

\section{CONCLUSIONS}

The fermentation time of each variety of potato was: in the court 30, native 45 days. And the tocosh obtained from the native potato variety has better sensory characteristics than the other treatments under study (taste, smell, consistency and overall appearance), obtaining the qualitative qualifier I am very pleased according to the qualification of the panelists.

The potato variety with the highest process yield in obtaining tocosh is the native variety with $53.3 \%$, followed by the canchan variety with $50.1 \%$

The potato variety with the highest process yield in the production of tocosh flour is the native variety with $59.6 \%$, followed by the variety Canchan $45.00 \%$.

\section{REFERENCES}

Alvarado, K., Esenarro, D., Rodriguez, C., \& Vasquez, W. (2020). Lemna minor influence in the treatment of organic pollution of the industrial effluents. 3C Tecnología. Glosas de innovación aplicadas a la pyme, 9(3), 77-97. https://doi. org/10.17993/3ctecno/2020.v9n3e35.77-97

Barrera, G. M., Blas, J. S., Landa, M. V., \& Sánchez, L. S. (2018). Tocoshana. Universidad Peruana de Ciencias Aplicadas (UPG). Universidad Peruana de Ciencias Aplicadas (UPG), Lima, Perú. https://repositorioacademico.upc.edu.pe/ handle/10757/625145 
Bustos, S. K. (2018). Exportación de yogurt de tocosh al mercado mexicano para mejorar la salud gastrointestinal, 2018 [Tesis de licenciatura]. Facultad De Ingeniería Y Negocios Escuela Académico Profesional De Negocios Y Competitividad. http:/ / repositorio. uwiener.edu.pe/bitstream/handle/123456789/2478/TESIS\%20Bustos\%20 Stefany.pdf ? sequence $=1$ \&isAllowed $=\mathrm{y}$

Carranza, K., Rodriguez, C., Esenarro, D., Veliz, M., \& Arteaga, J. (2020). Sensory evaluation of a perfume made of orange essential oil. International fournal of Chemical Engineering and Applications, 11(4). http:/ / www.ijcea.org/vol11/786-H3021.pdf

Córdova, A., Amaya, P., Esenarro, D., \& Rodriguez, C. (2020). Vegetable Contamination by Heavy Metal Contained in Effluents from Wastewater. Plant in the Totora Community, Ayacucho -Peru. Journal of Green Engineering, 10(7), 3484-3497.

Machaca, S. C., \& Mamani, R. V. (2020). Estudio comparativo del efecto antibacteriano de tres marcas del tocosh (Solanum tuberosum) frente a staphylococcus aureus ATCC 25923 Arequipa-2019. https://www.semanticscholar.org/paper/Estudio-comparativo-delefecto-antibacteriano-de-a-Machaca-Mamani/82c 1f081f7665e512dd737c60f69514 $\operatorname{cb} 8105250$

Quispe, W., Esenarro, D., Rodríguez, G., Alvarado, K., Ruiz, G., \& Alvarez, W. (2020). Physicochemical quality of honey bee (Apis mellifera) in three bioclimatic zones in Apurimac Perú. International fournal of Advanced Science and Technology, 29(7), 268-275. http://sersc.org/journals/index.php/IJAST/article/view/13219

Sandoval, M. H., Tenorio, J, Tinco, A., Ponce, R. A. L., \& Calderón, S. (2015). Efectos antioxidantes y citoprotectores de Solanum tuberosum 'papa' tocosh en mucosa gástrica en animales de experimentación. Anales de la Facultad de Medicina, 76(1), 15-20. https://doi.org/10.15381/anales.v76i1.11070

Velasco-Chong, J. R., Herrera-Calderón, O., Rojas-Armas, J. P., Hañari-Quispe, R. D., Figueroa-Salvador, L., Peña-Rojas, G., Andía-Ayme, V., Yuli-Posadas, R. Á., Yepes-Perez, A. F., \& Aguilar, G. (2020). TOCOSH FLOUR (Solanum tuberosum L.): A Toxicological Assessment of Traditional Peruvian Fermented Potatoes. Foods, 9(6), 719. https://doi.org/10.3390/foods9060719 